\title{
Ceramic fibre reinforced refractory castables for very high temperature superplastic forming
}

\author{
Keramikfaser verstärkte hochschmelzende Gießmassen für \\ superplastisches Umformen bei sehr hohen Temperaturen
}

\begin{abstract}
A. Mazzoni ${ }^{1}$, G. Bernhart ${ }^{1}$, T. Cutard ${ }^{1}$
In the frame of the development of very high temperature die material solutions, two grades of alumina based ceramic fibres with a diameter close to $12 \mu \mathrm{m}$ have been investigated as reinforcement solutions for an andalusite refractory castable. High temperature mechanical tests were performed up to $1200^{\circ} \mathrm{C}$ in four-point bending conditions: rupture tests at high temperature and anisothermal creep tests. After testing, microstructural and rupture surface were observed in order to get information on deformation mechanisms and rupture processes. Results show that significant mechanical improvement were obtained up to $1100^{\circ} \mathrm{C}$ when compared to non reinforced refractory castables.
\end{abstract}

Keywords: Refractory castable / superplastic forming / ceramic dies / ceramic fibre reinforcement / microstructure

Schlüsselwörter: Hochschmelzende Gießmassen / superplastisches Umformen / Keramikgesenk / Keramikfaser Verstärkung / Mikrostruktur

\section{Introduction}

Since several years, Fibre Reinforced Refractory Castables (FRRC) have been developed as an emerging material solution to manufacture tools in order to propose a low cost solution for Ti alloy sheet Superplastic Forming [1, 2]. Non-reinforced refractory castables keep good mechanical properties until $1000^{\circ} \mathrm{C}$ and are characterized by a good thermal shock resistance because of their low thermal expansion coefficient and low Young's modulus. Unfortunately, their mechanical behaviour remains quasi-brittle. It was demonstrated that the reinforcement with stainless steel fibres gives some ductility to the resulting FRRC and avoids a catastrophic failure after crack initiation.

Unfortunately when addressing higher temperatures, up to $1100^{\circ} \mathrm{C}$ as those that may be required for TiAl alloy, Superpalloy or duplex steel sheet superplastic forming, classical metallic reinforcement solutions are no more possible. In order to overcome this limit, alumina based ceramic fibre reinforcement solutions were investigated. This change does not only introduce a composition difference but also a major morphological evolution; as a matter of fact ceramic fibres have a diameter close to $12 \mu \mathrm{m}$ compared with the previous $500 \mu \mathrm{m}$ for the metallic ones and aggregates sizes that are close to $3 \mathrm{~mm}$.

\footnotetext{
${ }^{1}$ Université de Toulouse; INSA, UPS, Mines Albi, ISAE; ICA (Institut Clément Ader), Albi cedex, France
}

Corresponding author: Gerard Bernhart, Université de Toulouse; Mines Albi, ICA (Institut Clément Ader), F-81013 Albi cedex 09 France E-mail: gerard.bernhart@mines-albi.fr
After the description of fibre and castable matrix compositions, the processing route is shortly described and the high temperature mechanical properties under four-point bending conditions are reported. The non-reinforced castable is compared with two alumina fibre reinforcing solutions over the range from $700^{\circ} \mathrm{C}$ to $1200^{\circ} \mathrm{C}$. Interrupted and post rupture microstructural investigations have been performed in order to get an understanding of the internal micro-mechanical damage and fibrematrix load transfer mechanisms.

\section{Materials and experiments}

\subsection{Materials}

A commercial grade of an andalusite based refractory concrete (And-NF: Andalusite No Fibres) is considered in this work [3-5]. It is made of aggregates with a $5 \mathrm{~mm}$ maximum size, of silica fume, of alpha-alumina and of a low content of a calcium aluminate cement. The main properties of the two alumina-rich fibres investigated as reinforcing solutions (Nextel $720^{\circledR}$ and Nextel $610^{\circledR}$ ) are listed in Table 1 . The as delivered long mineral fibre tows were first cut to produce $12 \mathrm{~mm}$ short fibres and then mixed in a planetary mixer with the castable raw material and with $5 \mathrm{wt} \%$ water addition to produce the test samples.

After casting in a wood mould, mould and samples are then immediately wrapped in plastic. They are kept and dried at room temperature during $24 \mathrm{~h}$ and then extracted from the moulds before a $110^{\circ} \mathrm{C}-24 \mathrm{~h}$ drying step. Results on two grades of fibre reinforced andalusite concretes are reported in this paper and compared with the non reinforced one (And-NF): 
Table 1. Designation and properties of reinforcing fibres

\begin{tabular}{lll}
\hline Parameter & $\begin{array}{l}\text { Nextel } 720^{\circledR} \\
(\mathrm{N} 7)\end{array}$ & $\begin{array}{l}\text { Nextel 610 } \\
(\mathrm{N} 6)\end{array}$ \\
\hline Diameter $[\mu \mathrm{m}]$ & 12 & 12 \\
Length $[\mathrm{mm}]$ & 12 & 12 \\
Main constituents [wt\%] & $85 \% \mathrm{Al}_{2} \mathrm{O}_{3}$ & $>99 \% \mathrm{Al}_{2} \mathrm{O}_{3}$ \\
& $15 \% \mathrm{SiO}_{2}$ & \\
Young's modulus [GPa] & 260 & 380 \\
Tensile strength [MPa] & 2100 & 3100 \\
Maximum use temperature $\left[{ }^{\circ} \mathrm{C}\right]$ & 1800 & 2000 \\
Expansion coefficient $\left[\mathrm{K}^{-1}\right]$ & $6.0 \cdot 10^{-5}$ & $8.0 \cdot 10^{-5}$ \\
\hline
\end{tabular}

- grade And-N7 : And-NF reinforced with 2 vol.\% of Nextel $720^{\circledR}$ short fibres

- grade And-N6 : And-NF reinforced with 2 vol.\% Nextel $610^{\circledR}$ short fibres

Before performing microstructural or mechanical tests, a firing cycle is applied with a heating and cooling ramp of $60^{\circ} \mathrm{C} / \mathrm{min}$ including an isothermal dwell of 5 hours at maximum firing temperature. Before high temperature mechanical testing samples are heated with the same heating rate of $60^{\circ} \mathrm{C} / \mathrm{min}$ and subjected to a half hour dwell.

\subsection{Experiment procedures}

The four-point bending tests were carried out on a MTS810 servo-hydraulic universal testing machine and more details can be found in previous papers [6-8]. The samples, with a size of $150 \times 25 \times 25 \mathrm{~mm}^{3}$, were loaded at a constant crosshead speed of $0.2 \mathrm{~mm} / \mathrm{min}$. Applied load and beam deflection were recorded during the tests. Monotonic tests are performed at high temperature between $700^{\circ} \mathrm{C}$ and $1200^{\circ} \mathrm{C}$ using a resistive heating furnace and alumina testing fixtures. Fracture surfaces were observed at room temperature on a FEI-XL30-ESEM-FEG environmental scanning electron microscope.

\section{High temperature mechanical behaviour}

An increase of the non-linear domain of the behaviour curves is observed combined with an important increase of the strain capacity. Figure 1 shows that reinforcing the refractory concrete with alumina fibres modifies its behaviour over the whole temperature range. Moreover, this figure allows to notice that the mechanical characteristics of the refractory concrete is hardly modify with the testing temperature.

Figures $1 \mathrm{a}, 1 \mathrm{~b}$ and $1 \mathrm{c}$ show bending curves for the unreinforced And-NF refractory concrete and for Nextel $610^{\circledR}$ reinforced (And-N6) and Nextel $720^{\circledR}$ reinforced (And-N7) grades. Tests have been performed at $700^{\circ} \mathrm{C}, 900^{\circ} \mathrm{C}, 1000^{\circ} \mathrm{C}, 1100^{\circ} \mathrm{C}$ and $1200^{\circ} \mathrm{C}$. At $700^{\circ} \mathrm{C}$, the behaviour is quite similar for the three materials. After a linear elastic part, when the stress level increases, the behaviour moves to a non-linear one due to damage processes by microcracking. At higher stress levels, damage localizes and one or several macrocracks appear. After the stress peak, the behaviour curve exhibits an extended softening part. When comparing to stainless steel reinforced castables, fibre
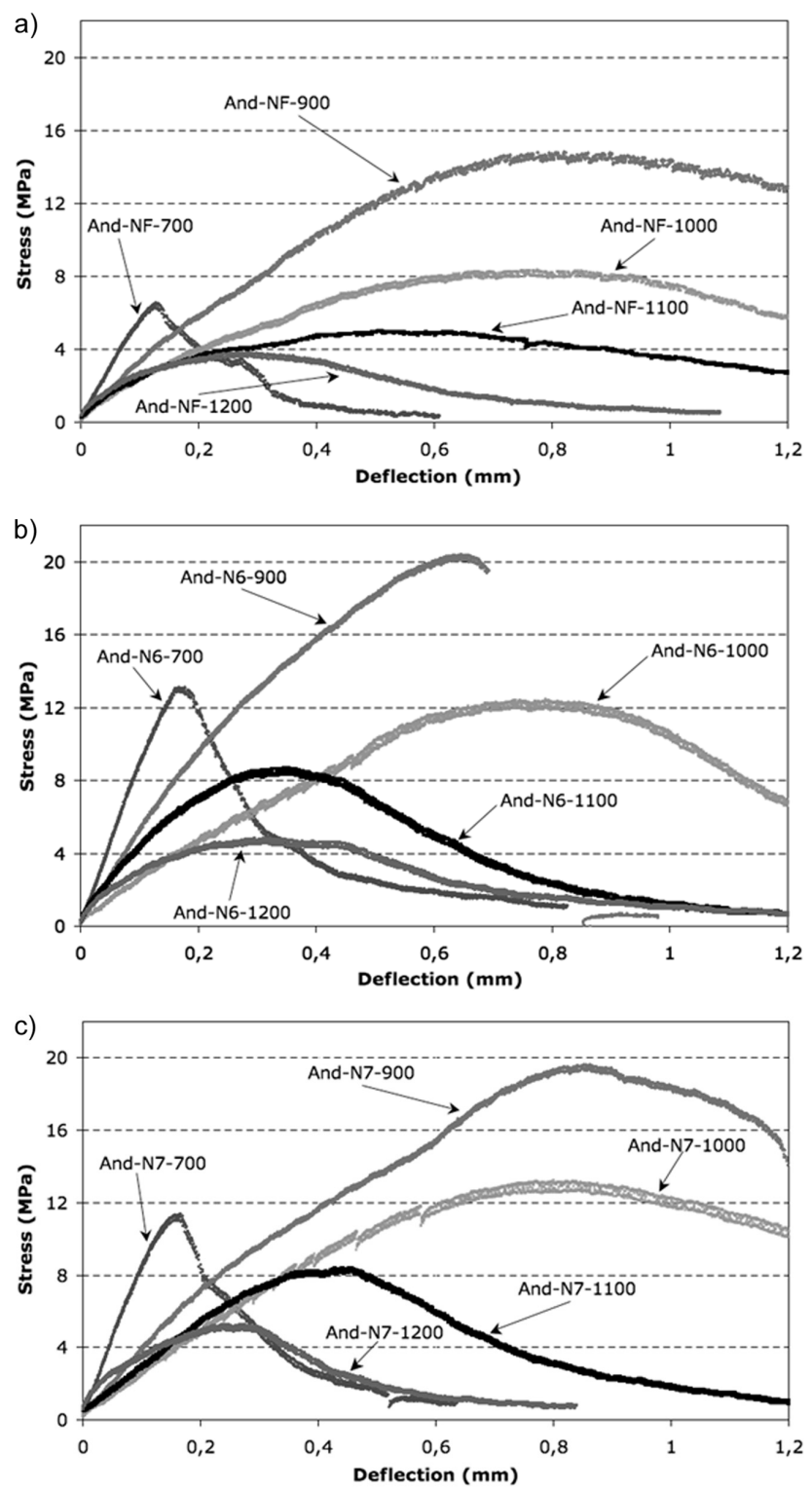

Fig. 1. Four-point bending behaviour curves of concrete fired and tested at high temperature between $700^{\circ} \mathrm{C}$ et $1200^{\circ} \mathrm{C}$ : a) unreinforced (And-NF), b) Nextel $610^{\circledR}$ (And-N6) and c) Nextel $720^{\circledR}$ (AndN7).

bridging is not so efficient and the post peak behaviour shows a rapid stress decrease, that is nevertheless not brittle [1,2]. At temperatures higher than $900^{\circ} \mathrm{C}$, general behaviour moves to a typical elasto-visco-plastic behaviour.

Reinforcing the And-NF concrete with Nextel fibres leads essentially to large modifications of the pre-peak behaviour. They mainly deal with an increase of the width of the pre-peak linear domain and with an increase of the stress peak and deflection peak levels. Nextel fibres can also be considered as delaying diffuse damage phenomena and to limit the visco-plastic behaviour of the concrete. Because of the high alumina content of Nextel fibres, the temperature range in which such phenomena can be 
Table 2. Peak stress relative variation at high temperature (four-point bending test)

\begin{tabular}{lrllll}
\hline $\begin{array}{l}\text { Testing } \\
\text { temperature }\end{array}$ & $700{ }^{\circ} \mathrm{C}$ & $900{ }^{\circ} \mathrm{C}$ & $1000{ }^{\circ} \mathrm{C}$ & $1100{ }^{\circ} \mathrm{C}$ & $1200{ }^{\circ} \mathrm{C}$ \\
\hline And-N7 & $86 \%$ & $79 \%$ & $96 \%$ & $52 \%$ & $31 \%$ \\
And-N6 & $117 \%$ & $65 \%$ & $73 \%$ & $51 \%$ & $41 \%$ \\
\hline
\end{tabular}

Unreinforced concrete is the reference

Table 3. Apparent elastic modulus relative variation at high temperatures (four-point bending test)

\begin{tabular}{llllll}
\hline $\begin{array}{l}\text { Testing } \\
\text { temperature }\end{array}$ & $700{ }^{\circ} \mathrm{C}$ & $900{ }^{\circ} \mathrm{C}$ & $1000{ }^{\circ} \mathrm{C}$ & $1100{ }^{\circ} \mathrm{C}$ & $1200{ }^{\circ} \mathrm{C}$ \\
\hline And-N7 & $44 \%$ & $16 \%$ & $110 \%$ & $12 \%$ & $49 \%$ \\
And-N6 & $36 \%$ & $22 \%$ & $85 \%$ & $49 \%$ & $49 \%$ \\
\hline
\end{tabular}

Unreinforced concrete is the reference

obtained is largely increased. No benefit effect is nevertheless observed in the post-peak domain

Table 2 and 3 gather respectively the peak stress and apparent elastic modulus relative variations of the reinforced And-NF castable and allow the quantification of the reinforcing effects. It can be seen that the addition of alumina-rich fibres increases the mechanical characteristics over the whole temperature range. The gain on the peak stress values varies between $9 \%$ and $96 \%$ for the And-N7 grade and between $41 \%$ and $117 \%$ for the AndN6 grade. For the apparent elastic modulus the gain varies between $12 \%$ and $110 \%$ for And-N7 grade and between $22 \%$ and $85 \%$ for And-N6 grade.

These first results of high temperature behaviour indicate that alumina-rich fibres have the capacity to delay the diffuse damage phenomena; fibres also modify the mechanisms that drive the visco-plastic concrete behaviour.

In order to study the visco-plasticity effect of the concrete, bending test were performed at $900^{\circ} \mathrm{C}$ in modifying the crosshead speed from $0.2 \mathrm{~mm} / \mathrm{min}$ to $0.02 \mathrm{~mm} / \mathrm{min}$, Figure 2. As it can be seen, dividing the displacement rate by a factor of 10 reduces the peak stress and the apparent modulus of the concrete without permitting a higher deformation capacity. For a given deflection value, a decrease of the strain rate causes a decrease of the stress values that has been related to the appearance of a liquid phase in the cementitious matrix [3]. The lower displacement rate allows a higher stress relaxation of the concrete. In Figure 2, the benefits of the alumina-rich fibre reinforcement can be observed, the higher the $\mathrm{Al}_{2} \mathrm{O}_{3}$ content the higher the load capacity: for the And-N6 grade tested at $0.2 \mathrm{~mm} / \mathrm{min}$, the stress gain is $80 \%$ for grade whereas for a rate of $0.02 \mathrm{~mm} /$ min, the gain is as high as $150 \%$.

Creep behaviour was also investigated under non-isothermal creep conditions: four-point bending samples were submitted to a constant $2 \mathrm{MPa}$ stress level whereas temperature was raised from $20^{\circ} \mathrm{C}$ to $1200^{\circ} \mathrm{C}$, Figure 3. Under such testing conditions, creep starts to occur between $750^{\circ} \mathrm{C}$ and $800^{\circ} \mathrm{C}$ whatever the grade. Results confirm that reinforcing the And-NF concrete with Nextel fibres increases its high temperature mechanical behaviour. Indeed, in all the temperature range, the measured
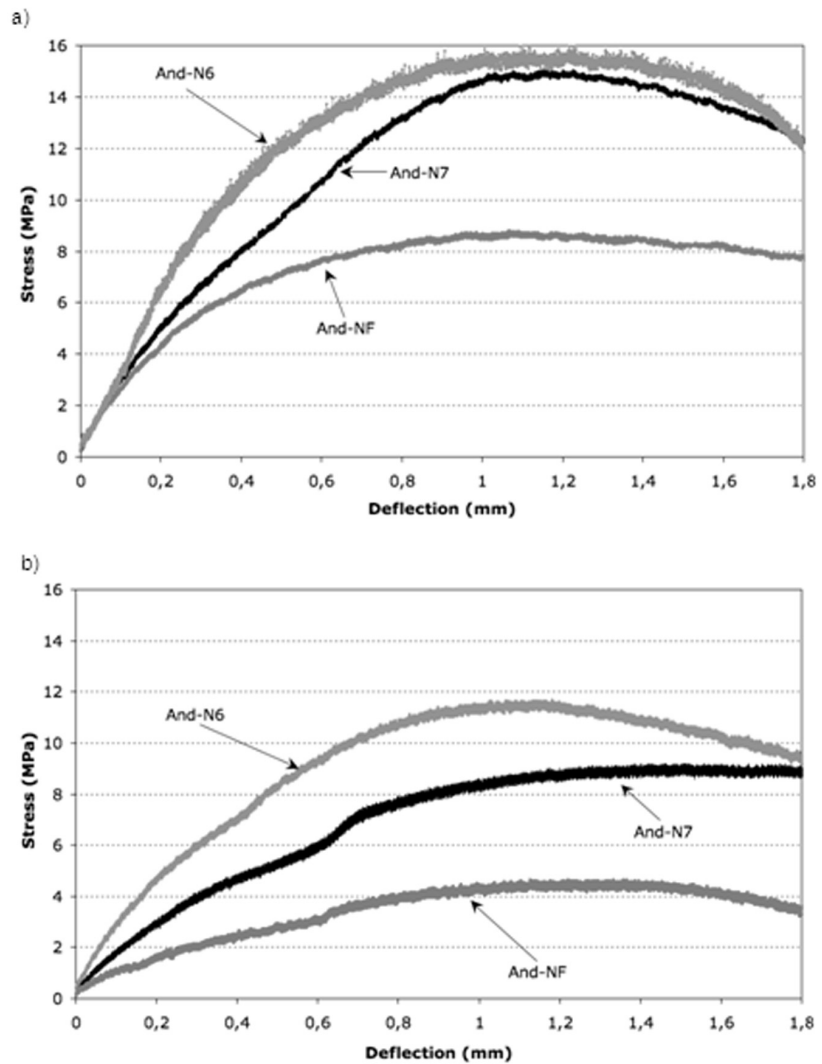

Fig. 2. Crosshead speed effect on four-point bending behaviour at $900{ }^{\circ} \mathrm{C}$ of the three grades: (a) $0.2 \mathrm{~mm} / \mathrm{min}$ and (b) $0.02 \mathrm{~mm} / \mathrm{min}$.

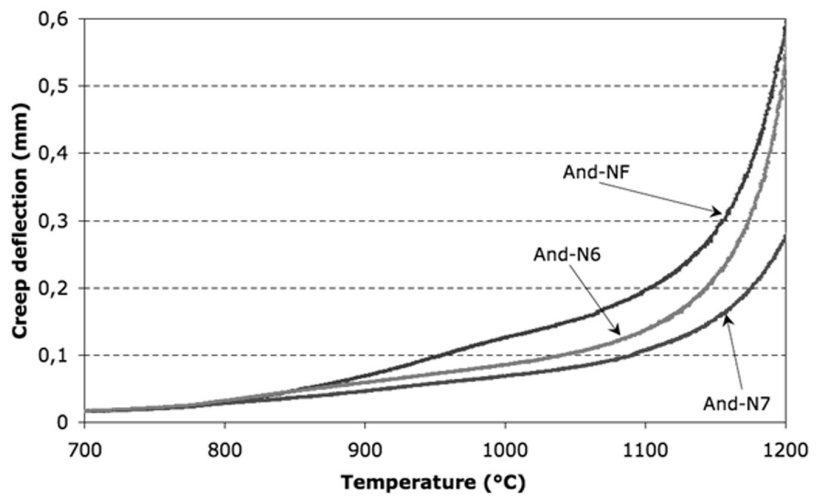

Fig. 3. And-NF, And-N6 and And-N7 grades anisothermal creep behaviour under $2 \mathrm{MPa}$ (four-point bending) until $1200^{\circ} \mathrm{C}$.

deflection levels are really lower for the reinforced grade up to $1100^{\circ} \mathrm{C}$, the And-N7 grade showing the better performances. After $1100^{\circ} \mathrm{C}$, a rapid creep deflection was observed for the AndN6 grade whereas And-N7 grade retains his creep resistance.

\section{High temperature microstructural evolution}

In order to identify the phenomena involved in the high temperature range, SEM observations were performed on samples after testing. 


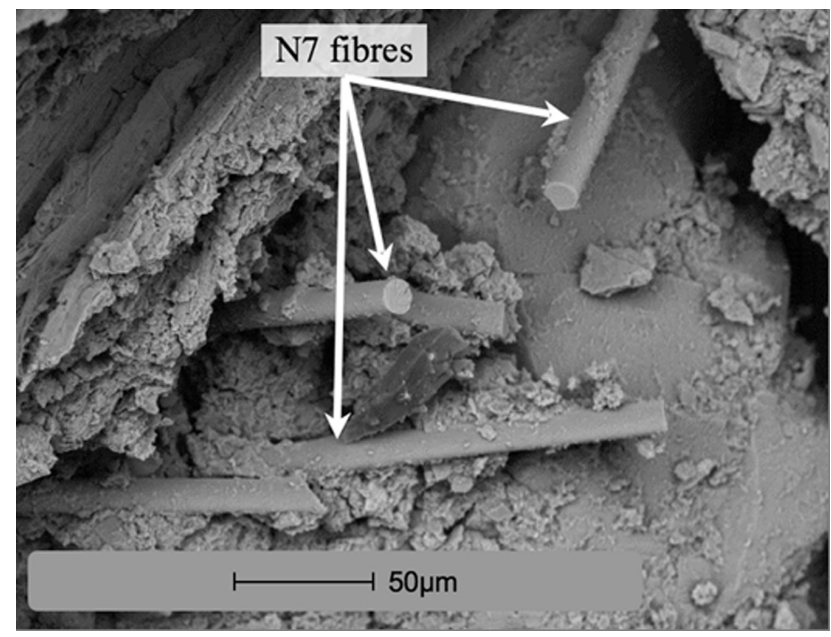

Fig. 4. Fracture surface of an And-N7 sample after a bending test at $900^{\circ} \mathrm{C}$ (SEM micrograph).

For the $900^{\circ} \mathrm{C}$ tested samples, Figure 4 shows a fracture surface with fibres that have been pulled out of the concrete. This indicates that debonding and sliding mechanisms act at the fibre/concrete interfaces. Such mechanisms must be considered as having a major role on the high temperature behaviour of the reinforced grades.

Previous studies have shown the microstructural evolution of the matrix concrete at high temperature (starting at $900^{\circ} \mathrm{C}$ ) and in particular the apparition of liquid phases in the matrix $[4,5]$. In order to observe the interaction between liquid phase and fibres, high magnification observations were completed on samples ruptured in the range $700^{\circ} \mathrm{C}-1200^{\circ} \mathrm{C}$. Figure 5 shows clearly the importance of the matrix microstructural evolution from a still cementitious matrix at $700^{\circ} \mathrm{C}$ towards a matrix with high liquid phases at higher temperatures. These images show that Nextel fibres reinforcement process involves also liquid phases at fibre/concrete interface.

During high temperature testing, the fibres modify the natural network of microcracks of the concrete. This can be seen on Fig- ure 6 showing microstructural observations on four-point bending test samples submitted to interrupted tests at $900^{\circ} \mathrm{C}$ (test stop took place before maximum stress peak). For both grades (And-N7 (a) and And-N6 (b)) numerous microcrack deviations, crack branching and bridging and fibre/matrix debonding configurations are visible (white arrows). As a consequence the presence of fibres slows crack propagation and opening. Debonding phenomena take extensively place both at matrix/aggregate interfaces and at matrix/fibre interfaces. The combination of all these phenomena is beneficial and partly explains the overall non-linear behaviour that is a mix between elastic-damageable and viscous contributions. However, at this scale, the specific effect related to the presence of liquid phase is difficult to observe especially after return to room temperature for observations.

Figure 7 highlights the role of fibres in the visco-plastic behaviour of the concrete at $1200^{\circ} \mathrm{C}$ and before a high level of damage. At this temperature, liquid phase amount of matrix is important and some vitreous phases could be seen. The observations partly help to explain the macroscopic viscoplastic deformation as a sliding mechanism between solid particles immersed in a large amount of liquid matrix phase. Such mechanisms are consistent with the increase of the strain capacity of the concrete and the stress accommodation phenomena in this high temperature testing domain. As a consequence the reinforced concrete becomes sensitive to strain rate. Moreover, many vitreous bridges are observed at fibres/matrix interfaces or between fibres. From this it can be considered that fibres can slow down or stop the relative displacement between the solid constituents of the matrix and modifying the rheology of the matrix at high temperature.

\section{Conclusion}

Ceramic fibre reinforced refractory castable have been studied in order to propose material solutions for die manufacturing for very high temperature Superplastic Forming. Two grades of Alumina based ceramic fibres with a diameter close to $12 \mu \mathrm{m}$ have been investigated as reinforcement solutions for an andalusite castable refractory and for temperatures higher than $900^{\circ} \mathrm{C}$.

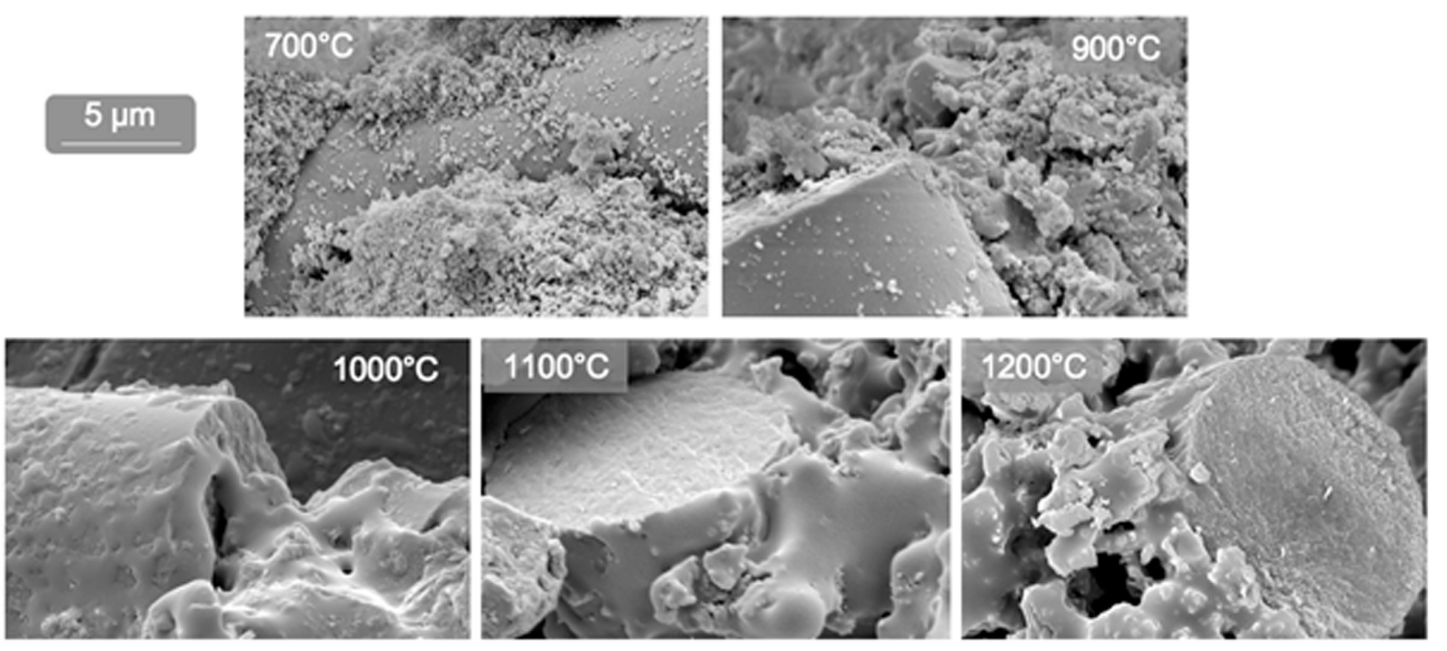

Fig. 5. Fracture surfaces of Nextel $720^{\circ}$ fibres and surrounding matrix after four-point bending tests in the temperature range $700^{\circ} \mathrm{C}$ to $1200^{\circ} \mathrm{C}$. 


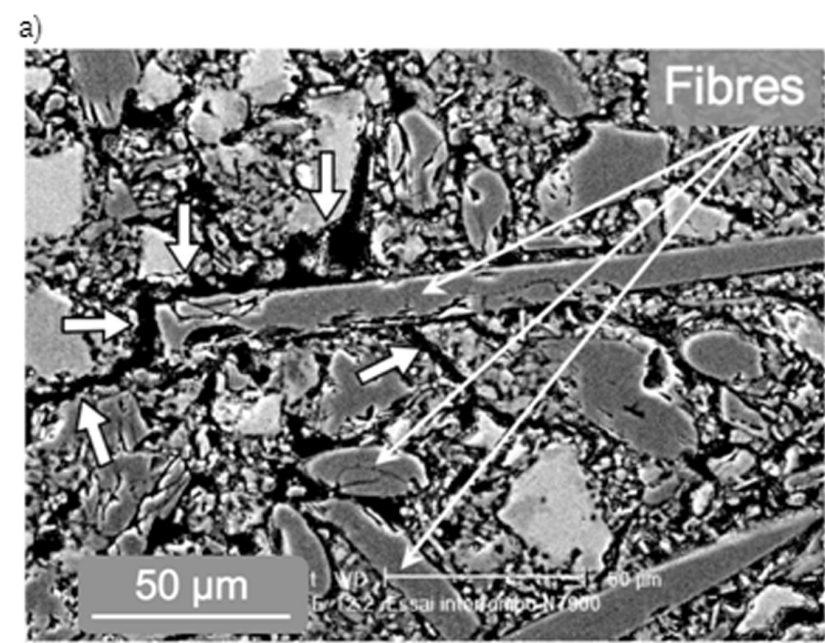

b)

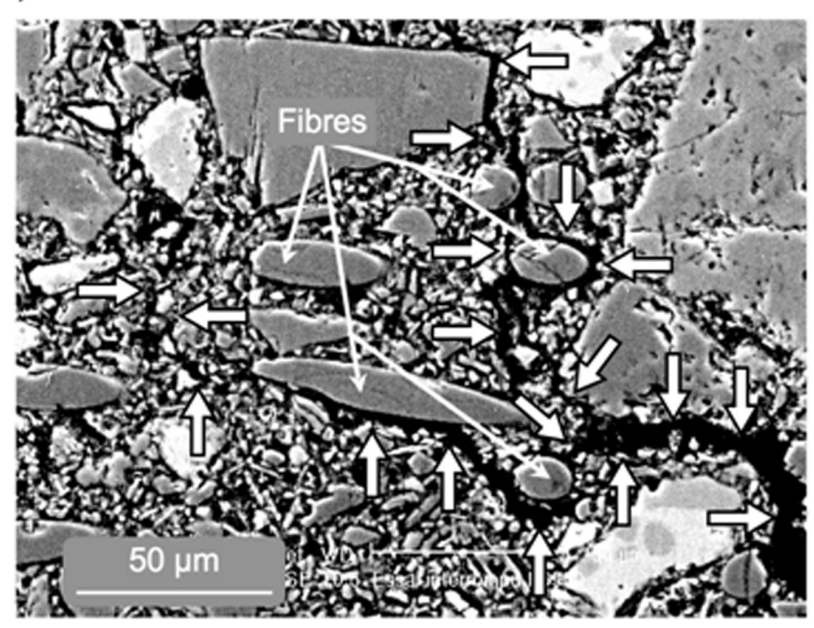

Fig. 6. Observation of diffuse damage developed during a $900{ }^{\circ} \mathrm{C}$ fourpoint bending test (interrupted before the peak stress) in an andalusite based castable reinforced with 2 vol.\% of: (a) Nextel720 ${ }^{\circledR}$ fibres (b) Nextel610 ${ }^{\circledR}$ fibres. White arrows indicate microcracks deviation phenomena to fibres.

High temperature mechanical tests were performed up to $1200^{\circ} \mathrm{C}$ in four-point bending conditions followed by after testing microstructural and rupture surface observations. Results show that significant mechanical and creep improvement were obtained up to $1100^{\circ} \mathrm{C}$ when compared to non reinforced refrac-

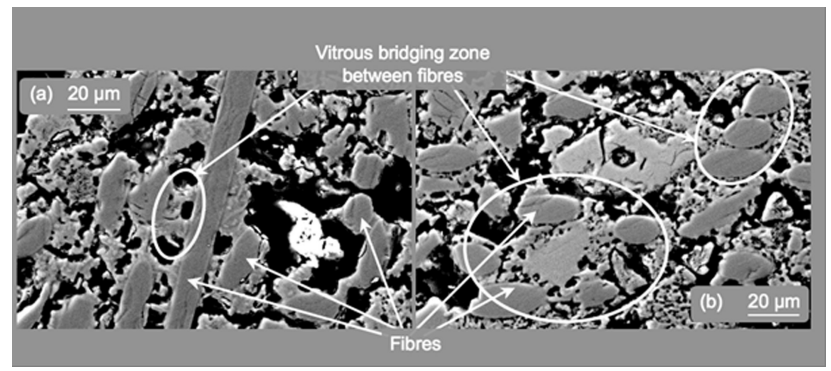

Fig. 7. Observation of And-N7 grade at room temperature after an interrupted four-point bending test at $1200^{\circ} \mathrm{C}$.

tory castables. These material solutions are now ready for industrial trial. At high temperatures, these materials exhibit a macroscopical visco-plastic behaviour, that has been related to microcracking branching and fibre/matrix debonding phenomena as well as numerous liquid phase appearance.

\section{References}

[1] G. Bernhart, F. Nazaret, T. Cutard, Materials Science Forum 2007, 37, 551-552.

[2] G. Bernhart, F. Nazaret, T. Cutard, Materialwissenschaft und Werkstofftechnik 2008, 39, 317.

[3] H. Marzagui, T. Cutard, Journal of Materials and Processing Technology 2004, 155-156, 1474.

[4] H. Marzagui, T. Cutard, M. Roosefid, E. Ouedraogo, N. Prompt, C. Deteuf, Proceedings of the International Conference of Metallurgists COM2004, Hamilton (Canada), 2004, 645-659.

[5] H. Marzagui, T. Cutard, E. Yeugo Fogain, M. Huger, C. Gault, N. Prompt, C. Deteuf, Proceedings of the International Conference of Metallurgists COM2004, Hamilton (Canada), 2004, 331-345.

[6] A. Mazzoni, PhD thesis (in French), Université Paul Sabatier (Toulouse-France), 2005.

[7] F. Nazaret, T. Cutard, G. Bernhart, Sixth RILEM Symposium on Fibre-Reinforced Concretes, Varenna (Italie), 2004.

[8] F. Nazaret, H. Marzagui, T. Cutard, Journal of the European Ceramic Society 2005, 26, 1429.

[9] T. Cutard, A. Mazzoni, UNITECR 2009, 11th Biennial Worldwide Conference on Refractories, October 13-16, 2009, Bahai (Brasil). 